ISSN: 2085-0344 (Print)

ISSN: 2503-1864 (Online)

Journal homepage: www.ejournal.almaata.ac.id/literasi

Journal Email: literasi_stia@yahoo.com

\title{
Implementasi Asco (Analyzing, Solving Problems, and Comparing) Terhadap Pembelajaran Membaca Kritis
}

\author{
Nuria Reny Hariyati \\ Akademi Farmasi Surabaya nuriareny@akfarsurabaya.ac.id \\ Hespi Septiana \\ Universitas Negeri Surabaya hespiseptiana@unesa.ac.id
}

\begin{abstract}
Abstrak
Penelitian tentang penanggulangan paparan isu radikal dengan berpikir kritis pada pembelajaranmembacakritis masihjarang dilakukan. Penelitianini bertujuanuntukmengetahui signifikasi pengaruh metode Asco (Analyzing, Solving Problems, Comparing) terhadap pembelajaran membaca kritis. Pendekatan penelitian ini menggunakan eksperimen kuasi the Times-Series Design with Control Group. Pengumpulan data penelitian ini adalah skor tes awal dan tes akhir. Kelompok eksperimen penelitian ini adalah kelas B2-18 dan kelompok kontrol, yakni kelas B3-18. Analisis data penelitian ini memakai uji One Way Anova SPSS for Windows dengan taraf signifikasi $<0.05$. Hasil penelitian ini adalah (1) Uji homogen kelompok 0.049 yang dinyatakan valid karena $>0.05$ untukmenguji hubungan ini; (2) Uji Anova kedua kelompok 0.000 yang dinyatakan signifikan karena $<0.05$. Hasil penelitian menunjukkan ada pengaruh secara signifikan Asco (Analyzing, Solving Problems, Comparing) pada pembelajaran membaca kritis.
\end{abstract}

Kata Kunci: Asco (Analyzing, Solving Problems, Comparing), Implementasi, Pembelajaran Membaca Kritis

\begin{abstract}
Research on overcoming exposure to radical issues with critical thinking on critical reading learning is still rarely done. This study aims to determine the significance of the effect of the Asco method (Analyzing, Solving Problems, Comparing) on critical reading learning.. This research approach uses the Quasi-Times Design Series with Control Group experiment. The research data collection, namely the initial test scores and final tests. The experimental group was B2-18 and the control group was B3-18. Data analysis of this study used the One Way Anova SPSS test for Windows with a significance level of $<0.05$. The results of this study, namely (1) A homogeneous group test of 0.049 which was declared valid because $>0.05$ to test this relationship; (2) Anova test of the two groups of 0,000 was declared significant because $<0.05$. The results showed that there was a significant influence of Asco (Analyzing, Solving Problems, Comparing) on critical reading learning.
\end{abstract}

Keywords: Asco (Analyzing, Solving Problems, Comparing), Implementation, Critical Reading Learning 


\section{PENDAHULUAN}

Membaca kritis saat ini menjadi komoditas penting untuk menyikapi wacana kritis yang banyak dijumpai di era literasi digital. Menurut ZA (2014); Ahyar (2015); Taufik (2015); Eva Farhah (2017); dan Hariyati dan Septiana (2019), maraknya wacana radikal juga menjadi perhatian dalam dunia pendidikan. Mahasiswa dijadikan acuan untuk menumbuhkembangkan ideologi tersebut. Paikah (2019) memaparkan bahwa Badan National Penanggulangan Terorisme (BNPT) menegaskan tiga ciri individu yang terpapar isu radikal, yaitu intoleran, fanatik, dan eksklusif. Realitas semacam ini sangat memerlukan pemecahan masalah. Pertama, secara psikologis seperti yang dipaparkan Ahmadi, Abd. Syukur Ghazali, Taufik Dermawan, and Maryaeni (2019) bahwa faktor personal juga sangat menentukan terpaparnya seseorang. Kedua, intoleran dengan masyarakat secara sosial juga memicu munculnya radikalisme. Ketiga, secara politik Hariyati dan Septiana (2019) memaparkan bahwa pemimpin negara hanya berpihak pada pihak tertentu juga memicu munculnya pemikiran radikal. Oleh sebab itu diperlukan penelitian yang melibatkan pembelajaran di kelas untuk menangkal wacana radikal. Penelitian yang relevan dengan membaca kritis telah dilakukan oleh Baek Jiyeon and Choi Jin Oh (2012); Hariyati and Syakur (2018); dan Hariyati dan Septiana (2019) yang menjelaskan tentang peningkatan membaca kritis dengan berbagai strategi di kelas. Dari penjelasan tersebut, dapat diketahui bahwa penelitian yang memakai metode Asco (Analyzing, Solving Problems, Comparing) dalam pembelajaran membaca kritis dalam rangka untuk menangkal isu radikal penting dilakukan.

Tujuan penelitian ini untuk mengetahui pengaruh implentasi Asco (Analyzing, Solving Problems, Comparing) terhadap pembelajaran membaca kritis. Urgensi penelitian ini untuk mewujudkan peningkatan kemampuan membaca kritis dengan metode analisis, memecahkan masalah, membandingkan wacana kritis.

\section{METODE PENELITIAN}

Pendekatan penelitian ini memakai eksperimen kuasi dengan The Times-Series Design with Control Group, yaitu pembentukan kelompok eksperimen dan kontrol dengan cara memilih kelas yang telah tersedia tanpa ada manipulasi dari peneliti. Kelompok eksperimen penelitian ini adalah kelas B2-18 dan kelompok kontrol penelitian ini adalah kelas B3-18. Alur pelaksanaan penelitian melalui tiga tahap, yaitu (1) tes awal; (2) kegiatan pembelajaran membaca kritis dengan metode Asco (Analyzing, Solving Problems, Comparing) selama enam kali pertemuan; dan (3) pelaksanaan tes akhir yang dijabarkan dalam tabel 1 berikut.

Tabel 1. Desain Penelitian

\begin{tabular}{llll}
\hline \multicolumn{1}{c}{ Group } & PreTest & Treatment & Postest \\
\hline Experiment & T1 & Critical Reading & T2 \\
Class B2-18 & & Learning & \\
Control & & with Asco & \\
Class B3-18 & (Analyzing, & \\
& & Solving Problems, \\
& & Comparing) method \\
& & Critical Reading \\
\hline
\end{tabular}

Pengumpulan data penelitian berupa skor tes awal dan skor tes akhir kelompok eksperimen dan kelompok kontrol. Instrumen penelitian ini meliputi dua hal, pertama, teks tes awal dan tes akhir berupa bacaan yang berisi wawasan isu-isu radikal (agama, politik, dan sosial) terkini. Kedua, tes menjawab pertanyaan. Kelompok diminta menanggapi dengan arahan, yaitu (1) kegiatan membaca teks dengan tema isu radikal; (2) kegiatan menanggapi teks dengan kisi-kisi menganalisis, penyelesaian masalah, dan membandingkan dengan teks yang lain yang mempunyai tema sama pada lembar jawaban yang telah disediakan; (3) kegiatan tes dilaksanakan dua kali selama satu semester pada mahasiswa reguler B tahun pembelajaran 2018/2019. Analisis data penelitian ini memakai uji One way Anova dengan SPSS for Windows, yakni untuk menguji signifikasi pengaruh Asco (Analyzing, Solving Problems, Comparing) terhadap pembelajaran membaca kritis tentang 
isu radikal. Uji Anova meliputi uji homogeny dua kelompok kemudian pelaksanaan uji Anova.

\section{HASIL DAN PEMBAHASAN}

Data penelitian yang terkumpul dengan pendekatan eksperimen kuasi the TimesSeries Design with Control Group, selanjutnya dianalisis dan hasilnya akan dijelaskan pada kajian hasil dan pembahasan sebagai berikut.

\section{Hasil}

Hasil penelitian ini disajikan dalam bentuk skor tes awal dan skor tes akhir yang dilaksanakan dua kelompok, yakni kelas eksperimen dan kelas kontrol. Pelaksanaan tes awal diikuti oleh 70 mahasiswa. Tiap kelas tes terdiri dari 35 mahasiswa. Kegiatan dilaksanakan selama satu semester. Kegiatan diawali dengan pelaksanaan tes awal, yakni (1) membaca teks dengan tema isu radikal; (2) menanggapi teks dengan menganalisis, penyelesaian masalah, dan membandingkan dengan teks yang lain yang mempunyai tema sama pada lembar jawaban yang telah disediakan. Kegiatan selanjutnya, pemberian perlakuan pada kelas eksperimen dengan pembelajaran membaca kritis dengan metode Asco (Analyzing, Solving Problems, Comparing), yakni mahasiswa berlatih meningkatkan kemampuan menganalisis, memecahkan masalah, dan membandingkan bacaan-bacaan yang disediakan. Skor pembelajaran membaca kritis dengan metode Asco (Analyzing, Solving Problems, Comparing) dapat dilihat dalam tabel 2.

Terakhir, pelaksanaan tes akhir. Skor tes akhir selanjutnya diuji Anova memakai SPSS for Windows yang dapat dilihat pada tabel-tabel berikut.

Tabel descriptives menunjukkan bahwa jumlah peserta tes sama, yakni 35 dengan total keseluruhan peserta tes 70 mahasiswa. Rerata skor kelas control diketahui 74,91 dan rerata kelas eksperimen diketahui 78,37. Hal ini menunjukkan kelas eksperimen memperoleh sor lebih tinggi. Tabel homogeneity menunjukkan
Tabel 2 Hasil Pembelajaran Asco di Kelas Eksperimen

\begin{tabular}{|c|c|c|c|c|c|}
\hline \multirow[b]{2}{*}{ No } & \multirow[b]{2}{*}{ T1 } & \multicolumn{3}{|c|}{ Pembelajaran Asco } & \multirow[b]{2}{*}{$\mathbf{T} 2$} \\
\hline & & Analyzing & $\begin{array}{c}\text { Solving } \\
\text { Problems }\end{array}$ & Comparing & \\
\hline 1 & 70 & 70 & 70 & 71 & 76 \\
\hline 2 & 70 & 70 & 72 & 75 & 79 \\
\hline 3 & 71 & 70 & 75 & 74 & 75 \\
\hline 4 & 76 & 67 & 76 & 75 & 77 \\
\hline 5 & 80 & 68 & 75 & 77 & 85 \\
\hline 6 & 79 & 71 & 76 & 78 & 79 \\
\hline 7 & 71 & 70 & 76 & 76 & 73 \\
\hline 8 & 73 & 74 & 78 & 75 & 77 \\
\hline 9 & 72 & 70 & 77 & 72 & 77 \\
\hline 10 & 72 & 70 & 77 & 73 & 77 \\
\hline 11 & 73 & 70 & 75 & 74 & 75 \\
\hline 12 & 75 & 72 & 76 & 75 & 80 \\
\hline 13 & 75 & 72 & 74 & 76 & 80 \\
\hline 14 & 76 & 78 & 73 & 75 & 80 \\
\hline 15 & 78 & 76 & 74 & 74 & 80 \\
\hline 16 & 79 & 74 & 76 & 74 & 85 \\
\hline 17 & 75 & 72 & 75 & 76 & 90 \\
\hline 18 & 75 & 71 & 76 & 78 & 78 \\
\hline 19 & 75 & 71 & 74 & 80 & 78 \\
\hline 20 & 75 & 72 & 78 & 79 & 78 \\
\hline 21 & 73 & 73 & 75 & 76 & 79 \\
\hline 22 & 74 & 73 & 79 & 85 & 79 \\
\hline 23 & 74 & 71 & 77 & 77 & 77 \\
\hline 24 & 74 & 75 & 77 & 75 & 75 \\
\hline 25 & 73 & 75 & 75 & 73 & 77 \\
\hline 26 & 73 & 75 & 72 & 74 & 79 \\
\hline 27 & 73 & 71 & 71 & 73 & 72 \\
\hline 28 & 75 & 71 & 76 & 74 & 75 \\
\hline 29 & 74 & 70 & 76 & 75 & 77 \\
\hline 30 & 73 & 79 & 74 & 77 & 77 \\
\hline 31 & 70 & 73 & 74 & 78 & 77 \\
\hline 32 & 74 & 78 & 73 & 79 & 76 \\
\hline 33 & 75 & 75 & 76 & 71 & 79 \\
\hline 34 & 75 & 78 & 77 & 72 & 80 \\
\hline 35 & 75 & 70 & 79 & 73 & 85 \\
\hline
\end{tabular}

signifikan 0.049, yang diartikan bahwa varian kedua kelompok sama atau layak untuk diuji Anova karena $0.049<0.05$, yang artinya signifikan. Tabel uji Anova kedua kelompok tes akhir menunjukkan skala $0,000<0,005$ yang diartikan bahwa ada perbedaan yang signifikan antara kedua kelompok tersebut. Hasil pelaksanaan tes awal dan tes akhir pada kelas eksperimen dan kelas control dapat dilihat pada grafik sebagai berikut. 
Tabel 3. Descriptives

Postest

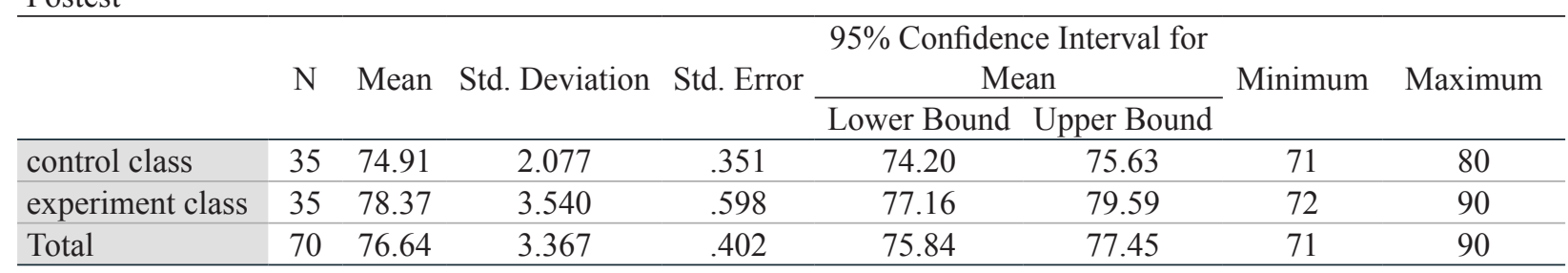

Tabel 4. Test of Homogeneity of Variances postest

\begin{tabular}{lccc}
\hline Levene Statistic & df1 & df2 & Sig. \\
\hline 3.936 & 1 & 68 & .049 \\
\hline
\end{tabular}

Tabel 5. Anova

postest

\begin{tabular}{lccccc}
\hline & $\begin{array}{c}\text { Sum of } \\
\text { Squares }\end{array}$ & Df & Square & S & Sig. \\
\hline Between & 209.157 & 1 & 209.157 & 24.825 & .000 \\
Groups & & & & & \\
Within Groups & 572.914 & 68 & 8.425 & & \\
Total & 782.071 & 69 & & & \\
\hline
\end{tabular}

Grafik skor tes awal dan tes akhir kelas eksperimen dan kelas control menunjukkan perolehan skor yang berbeda pada kedua kelas. Grafik skor tes awal yang berwarna biru menunjukkan perolehan skor tertinggi kelas eksperimen, yakni 80 sedangkan skor tertinggi kelas control, yakni 78. Grafik skor tes akhir yang berwarna hijau menunjukkan perolehan skor tertinggi kelas eksperimen, yakni 90 sedangkan skor tertinggi kelas Kontrol, yakni 80 Rerata tes awal kelas eksperimen dan kelas kontrol, yakni 73,86 dan rerata kelas eksperimen dan kelas kontrol, yakni 76,64. Hal ini menjelaskan skor tes akhir mengalami peningkatan.

\section{Pembahasan}

Pembahasan penelitian ini merupakan implementasi dari pemerolehan skor pembelajaran dengan metode Asco (Analyzing, Solving Problems, Comparing) yang diberikan pada kelas eksperimen sebagai bentuk perlakuan/treadment yang dapat dilihat pada tabel 2. Penelitian ini membahas Analyzing Implementation, Solving

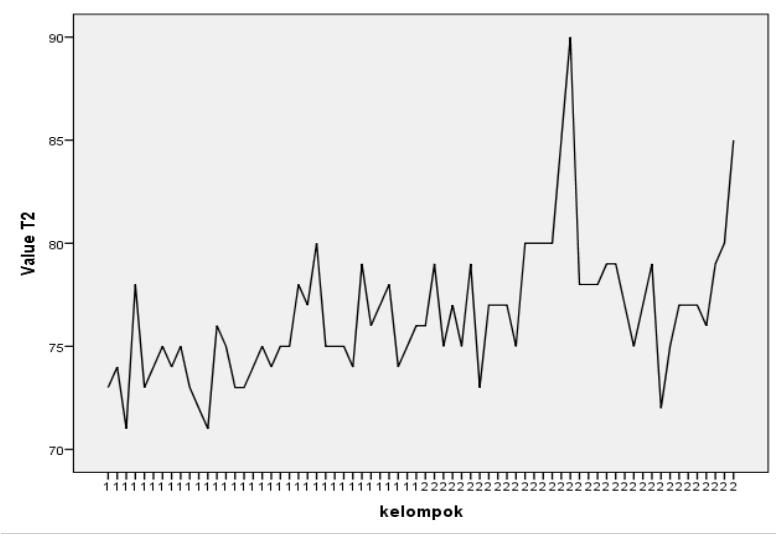

T1 tes awal

1 kelas kontrol

2 kelas eksperimen

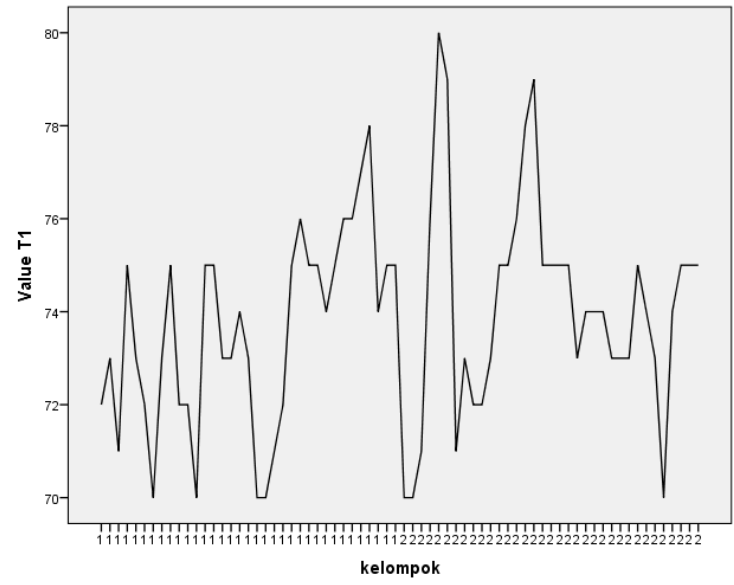

T2 tes akhir

1 kelas kontrol

2 kelas eksperimen

Problems Implementation, and Comparing Implementation dalam pembelajaran membaca kritis yang dijelaskan sebagai berikut.

\section{Implementasi Analyzing pada Pembelajaran Membaca Kritis}

Hasil penelitian menunjukkan bahwa menganalisis berpengaruh terhadap pembelajaran 
membaca kritis. Data menunjukkan perbedaan yang signifikan antara kelas eksperimen dan kelas kontrol pada pelaksanaan tes akhir. Kemampuan menganalisis dalam kegiatan membaca kritis meliputi kegiatan membaca dengan memperhatikan alur mengurai ide penulis yang tertuang dalam bacaan kemudian memilah cara pandang penulis menangkap ide-ide tersebut dan menginterpretasinya lebih dalam. Kedalaman menganalisis tidak hanya sekadar menemukan alasan mengapa penulis mengatakan demikian tetapi menangkap kebenaran yang disampaikan penulis.

Penelitian sebelumnya yang membahas tentang membaca kritis dipaparkan oleh Ham (2016); Robinson (2017); dan Holm (2018) yang membahas tentang analisis membaca kritis dari pembacaan narasi dan disposisi elite politik. Implikasi menganalisis dalam kegiatan membaca kritis, yakni peningkatan penguasaan bacaan dengan melihat fakta-fakta yang ada; peningkatan ketajaman berpikir kritis pembaca; dan peningkatan pengklasifikasian masalahmasalah yang dimunculkan penulis dalam ranah keakuratan informasi dalam bacaan. Pembaca kritis diharapkan melihat fakta-fakta, detil-detil penunjang, atau unsur pembentuk yang lain yang tidak disebutkan secara terbuka. Lebih lanjut, Ham (2016); Robinson (2017); dan Holm (2018) menegaskan kemampuan itu dikembangkan menjadi kemampuan pembaca melihat kesatuan gagasan melalui bagianbagiannya.

\section{Implementasi Solving Problems pada Pembelajaran Membaca Kritis}

Berdasarkan hasil penelitian diketahui terdapat pengaruh kegiatan menyelesaikan masalah terhadap pembelajaran membaca kritis. Data menunjukkan bahwa terdapat perbedaan yang signifikan antara kelas eksperimen dan kelas kontrol pada pelaksanaan tes akhir. Kemampuan menyelesaikan masalah dalam pebelajaran membaca kritis, yakni menuntaskan masalah-masalah yang muncul dalam bacaan dengan cara mengurai alur datangnya informasi yang disajikan penulis
Penelitian sebelumnya yang membahas tentang penyelesaian masalah dalam pembelajaran membaca kritis Reichenberg (2012); Allen (2019); dan Atanasova (2019) menyatakan tentang menyelesaiakan permasalahan dalam pembelajaran. Implikasi menyelesaikan masalah dalam kegiatan membaca kritis penelitian ini, yakni mahasiswa dapat meluruskan informasi yang rumpang dalam bacaan dan menghasilkan kemampuan berpikir kritis.

\section{Implementasi Comparing pada Pembelajaran Membaca Kritis}

Hasil penelitian menunjukkan bahwa membandingkan berpengaruh terhadap pembelajaran membaca kritis. Data menunjukkan bahwa terdapat perbedaan yang signifikan antara kelas eksperimen dan kelas control pada pelaksanaan tes akhir. Kemampuan membandingkan dalam pembelajaran membaca kritis, yakni menghubungkaitkan antargagasan dalam bacaan; membandingkan latar penulis satu dengan penulis lainnya; menghubungkan simpulan pada tiap bacaan yang diperbandingkan kemudian membuat simpulan baru yang lebih kuat nilainya.

Penelitian sebelumnya yang membahas tentang membandingkan dalam pembelajaran membaca kritis Chittooran (2015); Zou (2016); dan Alem (2019) yang membahas tentang kegiatan membandingkan kegiatan pembelajaran di lingkungan sekolah. Implikasi membandingkan pada kegiatan membaca kritis dalam penelitian ini, yakni dapat menghubungkan dan mengoreksi permasalahan yang tersaji dalam bacaan; dapat menyimpulkan dengan benar permasalahan yang muncul pada bacaan.

\section{KESIMPULAN}

Penerapan Asco (Analyzing, Solving Problems, Comparing) pada pembelajaran membaca kritis mempunyai pengaruh yang signifikan sehingga diindikasi dapat menanggulangi isu-isu radikal yang masuk di perguruan tinggi. Selain itu, dapat diketahui bahwa penanggulangan isu-isu 
radikal dapat ditangkal melalui pembelajaran membaca kritis tidak hanya melalui kontra radikalisasi dan deradikalisasi yang digagas Badan Nasional Penanggulangan Terorisme (BNPT) saja. Harapannya setelah ini, Asco (Analyzing, Solving Problems, Comparing) dapat direalisasikan dan dikembangkan dalam kegiatan pembelajaran membaca kritis di seluruh perguruan tinggi.

\section{UCAPAN TERIMA KASIH}

Artikel ini dibiayai oleh Direktorat Riset dan Pengabdian Masyarakat, Direktorat Jenderal Penguatan Riset dan Pengembangan Kementerian Riset, Teknologi, dan Pendidikan Tinggi Republik Indonesia sebagai luaran Penelitian Dosen Pemula 2019.

\section{DAFTAR PUSTAKA}

Ahmadi, A., Abd. Syukur Ghazali, Taufik Dermawan, and Maryaeni. 2019. "Ecopsychology and Psychology of Literature: Concretization of Human Biophilia That Loves the Environment in Two Indonesian Novels." The International Journal of Literary Humanities 17 (1): 47-59. doi:10.18848/2327-7912/CGP/ v17i01/47-59.

Ahyar, M. (2015). Membaca Gerakan Islam Radikal dan Deradikalisasi Gerakan Islam. Walisongo: Jurnal Penelitian Sosial Keagamaan, 23(1), p.1.

Alem, Y. T. (2019). Critical Reflection as Motivational Strategy of Learning Critical Reading. Journal of Language Teaching and Research, 10(4), 683. doi: 10.17507/ jltr.1004.03.

Allen, T. (2019). Narrative design thinking. Solving Critical Design Problems, 171183. doi: 10.4324/9780429398872-12.

Atanasova, G. (2019). Students' Critical Thinking Skills Improvement Via Algorithmic Problems Solving. EDULEARN19 Proceedings. doi: 10.21125/edulearn.2019.2079.

Baek Jiyeon and Choi Jin Oh (2012). The Effects of a Reading Comprehension Monitoring
Strategy on Critical Reading, Reading Efficacy, and Reading Attitudes. Journal of Research in Curriculum Instruction, 16(2), pp.421-439.

Chittooran, M. M. (2015). Reading and Writing for Critical Reflective Thinking. New Directions for Teaching and Learning, 2015(143), 79-95. doi: 10.1002/t1.20137.

Eva Farhah, I. (2017). Gerakan Islam Radikal dan Terorisme di Indonesia: Kajian Terhadap Upaya Integrasi Bangsa. Jurnal CMES, 6(2), p.124.

Ham, V. V. D. (2016). Reading with a critical mindset. Analyzing a Case Study, 17-18. doi: 10.1007/978-1-137-56621-8_5.

Hariyati, N. and Septiana, H. (2019). Effectiveness of Critical Thinking about Radicalism Issue (CTRI) on Critical Reading Activities: A Quasi Experimental Study. International Journal of Multicultural and Multireligious Understanding, 6(3), p.1055.

Hariyati, N. and Septiana, H. (2019). Buku Ajar Membca Kritis: radikalisme dalam Perspektif Analisis wacana Kritis, Gresik, Graniti. Hal 6-12.

Hariyati, N. and Syakur, A. (2018). Penerapan Strategi Membaca Kritis di Akademi Farmasi Surabaya untuk Menunjang Kecakapan Literasi Menuju Era Revolusi Industri 4.0. Makalah disajikan pada Seminar Nasional Edusaintek: Pembelajaran Kolaborasi Berbasis ICT Menuju Era Revolusi Industri 4.0. Unimus. Hal 450-455.

Holm, N. (2018). Critical capital: cultural studies, the critical disposition and critical reading as elite practice. Cultural Studies, pp.1-24.

Paikah, N. (2019). Kedudukan dan Fungsi Badan Nasional Penanggulangan Terorisme (BNPT) Dalam Pemberantasan Terorisme di Indonesia. Al-Adalah: Jurnal Hukum dan Politik Islam, 4(1), pp.1-20.

Reichenberg, M. (2012). Special issue Reading: A critical conceptual analysis. Comments on five contributions. L1 Education 
Studies in Language and Literature, 11(Reading: A critical analysis), pp.9196.

Robinson (2017). Marx after post-narratives: a critical reading of Ronaldo Munck's critical reading of Marx. Global Discourse, 7(4), pp.602-608.

Taufik, M. (2015). Pandangan Kritis Islam Liberal atas Isu-Isu Kontemporer.
Al-Banjari : Jurnal Ilmiah Ilmu-Ilmu Keislaman, 14(1).

ZA, T. (2014). Isu-Isu Kritis dalam Pendidikan Islam Perspektif Pedagogik Kritis. Jurnal Ilmiah Islam Futura, 13(2), p.250.

Zou, D. (2016). Comparing Dictionary-induced Vocabulary Learning and Inferencing in the Context of Reading. Lexikos, 26(1). doi: 10.5788/26-1-1345. 